\title{
NOWE SUGESTIE DOTYCZĄCE WIEDZY O PIEKLE
}

Problematyka duszy w życiu pozagrobowym jest jednym z podstawowych obszarów zainteresowania katolików oraz innych wyznań chrześcijańskich. Odnosi się to również do większości wyznawców pozostałych religii, których pragnienie życia po śmierci wypełnionego radością i w obecności Boga motywuje do jeszcze gorliwszej praktyki swojej religii. Mają oni zbawczą nadzieję zasłużyć na najwyższą nagrodę za życie dobrze przeżyte $\mathrm{w}$ wierze w Boga ${ }^{1}$. Ponadto są oni prawdopodobnie równie umotywowani lękiem przed sytuacją odwrotną, która skutkowałaby wiecznym cierpieniem, z dala od Boga, który zostałby na zawsze utracony. Wielu osobom, poza troską o swój własny los, towarzyszy obawa o przyszłość swoich bliskich w życiu pozagrobowym. Czyny człowieka są kluczowe dla jego zbawienia, ale wydaje się, że niewiele można zrobić, aby pomóc członkom rodziny lub przyjaciołom, którzy nie poświęcają się Bogu i Kościołowi w dążeniu do radości życia wiecznego. Jeszcze mniej osób niepokoi się o los miliardów ludzi na całym świecie, którzy wyznają inną wiarę lub nawet nie wierzą wcale. Można modlić się za świat, za przyjaciół i rodzinę, lecz działania te nie są wystarczające, aby zapewnić im zbawienie. W konsekwencji niektórzy wierzący pytają czy nauka o niebie i piekle jest w pełni zrozumiała. Choć wydaje się oczywiste, dzięki wielu odniesieniom w Biblii, że piekło istnieje, ludzie ci zastanawiają się nad prawdziwą pewnością losu grzesznika. Niektórzy formułują takie właśnie pytanie dotyczące natury Boga: Czy kochający Bóg mógłby wysyłać swoje stworzenie na wieczne cierpienie? Inni zastanawiają się czy poprawnie rozumiemy istotę i cel piekła, patrząc na Pismo Święte i inne źródła w poszukiwaniu wskazówek co do tego, czy piekło jest w rzeczywistości zarezerwowane dla ogromnej liczby ludzi, którzy nie znaleźli Boga za pośrednictwem Kościoła katolickiego i nie oddali się Jemu.

1 Por. M. Kowalczyk, Zbawczy wymiar nadziei w encyklice Benedykta XVI ,, Spe salvi”, „Ateneum Kapłańskie" 103(2012), t. 158, z. 3, s. 507-524. 
Kwestia ta jest złożona, ponieważ zawiera w sobie wiele najważniejszych aspektów zrozumienia religii, w tym istotę życia pozagrobowego i konsekwencje nieposłuszeństwa Bogu w obecnym życiu.

\section{OZNAKI NADZIEI NA POWSZECHNE ZBAWIENIE W BIBLII}

Biblia w naturalny sposób odnosi się do życia pozagrobowego i w wielu miejscach zawiera refleksję lub nawoływanie do spełnienia warunków, które mogłyby doprowadzić do wiecznego szczęścia, lub też zgryzoty. Na przykład Pierwszy list do Koryntian obiecuje życie wieczne w świetle Bożej miłości, stanowczo oświadczając, że ,jak w Adamie wszyscy umierają, tak też w Chrystusie wszyscy będą ożywieni” (1 Kor 15,22). Lamentacje stwierdzają, że „(...) nie jest zamiarem Pana odtrącić na wieki” (Lm 3,31). Ci, którzy sprzeciwiają się twierdzeniu, że powyższe powoduje bezsensowność aktu wiary, rozważają fragment Pierwszego listu do Tymoteusza, który wprowadza pewne rozróżnienie, bez potępiania kogokolwiek na wieki, ogłaszając, że „Bóg żywy (...) jest Zbawcą wszystkich ludzi, zwłaszcza wierzących" (1 Tm 4,10). W Liście do Kolosan Jezus jest opisany jako ten, który poprzez swoje wcielenie pojednał wszystkich z Bogiem (por. Kol 1,20).

Pomimo tych dowodów oraz wielu innych przykładów, istnieją inne miejsca w Biblii, gdzie wydaje się bardzo jasne, że nie wszyscy ludzie znajdą się przy Panu po śmierci. Jezus mówi w pewnym momencie, że drzwi, przez które ludzie będą musieli wejść do Królestwa Niebieskiego będą ciasne (por. Łk 13,23-25). Gdzie indziej twierdzi On, że łatwiej jest wielbłądowi przejść przez ucho igielne, niż bogatemu wejść do Nieba (por. Mt 19,24, Mk 10,25). W przypowieści opisuje On bogatego człowieka w ogniu piekielnym, który prosi Boga, by pozwolił Łazarzowi umoczyć palec w wodzie i ochłodzić jego język (por. Łk 16,14-31). Z przypowieści tej płynie wniosek, że piekło istnieje i ktoś tam spędzi trochę czasu.

Św. Paweł oświadczył, że chętnie poszedłby do piekła, aby ocalić swoich żydowskich braci i siostry (por. Rz 9,1-4). Takie radykalne oświadczenie osoby tak pobożnej i wykształconej, jak Paweł, oddaje powagę tej kwestii oraz stopień, w jakim dręczy ona najbardziej wrażliwych wiernych. Oczywiście, św. Paweł wiedział, że jego wieczność w piekle nie miałaby żadnego wpływu na losy innych Żydów, ale jego oświadczenie ma jednak ogromne znaczenie, co zostanie jeszcze później omówione ${ }^{2}$. Teraz słowa św. Pawła spróbujmy rozpatrywać w oparciu o ich wartość jako wskaźnika znaczenia kwestii duchowego losu innych. Jest to raczej praktyczny punkt widzenia, który sprawia, że myślimy o naszym duchowym przeznaczeniu w kontekście sytuacji innych. Bardzo wiele osób przez całe życie

2 Por. H.U. von Balthasar, Dare We Hope „, That All Men Be saved”? [Mamy nadzieję ze wszyscy będa zbawieni], Ignatius Press, San Francisco 2014, s. 164-168. 
dręczą kwestie związane z zachowaniem innych. W rzeczywistości można by argumentować, że Jezus nakazuje nam nie koncentrować się na zachowaniu innych ludzi, ponieważ to my będziemy sądzeni, więc nie powinniśmy osądzać innych (por. Mt 7,1-2). Co więcej, przypomina, że ludzie czasami zwracają uwagę na niewielki defekt u innych, oceniając go surowo, pomijając przy tym ogromną wadę u siebie (por. Mt 7,3-5). Według Niego, tacy ludzie są hipokrytami, a określenie to zarezerwował dla ludzi, w stosunku do których był najbardziej krytyczny (Por. Mt 7,5). Inni jednak dbają o los bliźnich prawie od samego początku ich drogi duchowej, a dla jeszcze innych jest to kwestia podstawowa. Dla wielu tych ludzi Dobra Nowina jest odpowiedzialnością wymagającą pewnego doskonalenia. Jak zostało powiedziane w Biblii, światło powinno być na statywie do oświetlania domu, a nie w koszu lub pod korcem (por. Mt 5,15; Łk 11,33). Oczywiście, wiedza dotycząca drogi do zbawienia i wiecznego światła powinna być traktowana jako źródło światła, jeśli cokolwiek mogłoby nim być. Nie znaczy to, że trzeba ewangelizować w następstwie poznania drogi do zbawienia, lecz łączyć własne wewnętrzne światło ze światem. Sposób tego połączenia jest mniej istotny niż sam fakt połączenia w ten czy inny sposób. Nawet jeśli szuka się zbawienia jedynie dla siebie, przynosi to dla świata konsekwencję tak, jakby szukało się go także dla innych. Są osoby, na które moglibyśmy wpłynąć, lecz tego nie czynimy, utrzymując swoje światło i zbawienie w tajemnicy ${ }^{3}$. Ten rodzaj myślenia prowadzi niektórych do zastanawiania się, jakie znaczenie ma mieć dla nich zbawienie ich bliźnich oraz jak ważne jest to dla stanu ich własnej duszy. To zaczątek stanu, który może później doprowadzić do szerszego zrozumienia powiązania ze sobą zbawienia nas wszystkich, tego powszechnego zbawienia, które niektórzy przyjmują, a inni odrzucają. Biorąc pod uwagę, że sprawa ta dotyczy każdego człowieka na tej planecie, jest to bardzo poważny temat, zasługujący na dogłębne rozważenie ${ }^{4}$.

\section{OJCOWIE KOŚCIOEA I TEOLOGOWIE KATOLICCY O POWSZECHNYM ZBAWIENIU}

Powszechne zbawienie jest poglądem głoszącym, że każdy w końcu będzie przebywać w obecności Boga po wieczność i ma długą oraz skomplikowaną historię. Pogląd ten nie jest zwykłym optymizmem i budzi poważne wątpliwości co do roli sprawiedliwości we wszechświecie oraz celu i planu wcielenia Jezusa. Katolicy omawiali tę kwestię przez wieki, a zyskała ona wyjątkową wagę po

Por. C. Parzyszek, Nowa Ewangelizacja-droga Kościoła do nadziei, Apostolicum, Ząbki 2010, s. 261-272; R. Martin, The Urgency of the New Evangelization:Answering the Call. [Pilność nowej ewangelizacji: odpowiadanie na wezwanie], Our Sunday Visitor, Indiana 2013, s. 23-36.

4 Por. C. Parzyszek, Znaczenie nowej ewangelizacji dla odnowy współczesnego świata, Apostolicum, Ząbki 2012, s. 155-169; SSa 48. 
Soborze Watykańskim II, kiedy to ważna zmiana poglądu Kościoła na zbawienie jeszcze bardziej zainspirowała dyskusję na temat powszechnego zbawienia ${ }^{5}$.

Istnieje długa lista wczesnych ojców Kościoła, których uważa się za aprobujących koncepcję powszechnego zbawienia, są na niej: Klemens Aleksandryjski, Ambroży oraz Grzegorz z Nyssy ${ }^{6}$. Pierwotnie przypisywało się to Grzegorzowi z Nyssy ${ }^{7}$. Diodor z Tarsu, który żył w IV wieku n.e., twierdził, że: „Dla niegodziwych są kary, nie wieczne, jednak, (...) ale mają być oczyszczane przez krótki okres, zależnie od ilości złośliwości w ich pracach. Dlatego cierpią na krótką przestrzeń, ale czeka ich nieśmiertelność błogosławieństwa (...) a kary, które na nich czekają za wiele ich ciężkich grzechów, są znacznie przewyższane wielkością miłosierdzia, które będzie im okazane"». Św. Teofil z Antiochii uważał, że „(...) Bóg okazał wielką życzliwość człowiekowi, w tym, że nie trzymał go w cierpieniu w grzechu po wieki; ale tak, jak to się stało, dzięki pewnego rodzaju banicji wyrzucił go z raju po to, aby po odkupieniu swych grzechów w wyznaczonym czasie po poniesieniu kary, ponownie zbliżył się do Boga". Ireneusz z Lyonu, który żył w drugim stuleciu w czasach Teofila, również uważał, że każda kara następująca po życiu będzie tymczasowa według naszych ziemskich standardów. Św. Hieronim stwierdził, że „na końcu czasów, przy spełnieniu się wszechświata, wszystko zostanie przywrócone do stanu pierwotnej harmonii" ${ }^{10}$. Uzasadnienie powyższych opinii jest zróżnicowane, wynika jednak z odmiennych, znaczących szkół myślenia. Według Ireneusza „Bóg mu współczuł i zapragnął, aby ten nie był nieśmiertelny, a zło nie było nieskończone i nieodwracalne" ${ }^{11}$. Św. Teofil rozumował, że „z człowiekiem po śmierci będzie tak jak z naczyniem, które okazuje się posiadać wadę i zostaje poprawione lub utworzone od nowa tak, że ponownie jest nowe i kompletne"12. Powyższe fragmenty przedstawiają dwa z najważniejszych podejść wczesnych ojców Kościoła. Jedno z nich zakłada, że Bóg nie ma planu niekończącej się kary dla swego stworzenia. W drugim zaś, Boży plan dla każdego człowieka powinien ostatecznie zakładać doskonałość, czas, kiedy wzrośnie dzięki karze i stanie się gotowy do komunii z Bogiem.

5 Por. J. Finkenzeller, Eschatologia. Podręcznik teologii dogmatycznej, Wydawnictwo M, Kraków 1995, s. 213-217.

6 G. Amirault, M. Amirault, The Church Fathers on Universalism [Ojcowie Kościoła o uniwersalizmie], http://www.tentmaker.org/Quotes/churchfathersquotes.htm (3.6.2016).

7 R. Martin, Will many Be Save? What Vatican II Actually Teaches and Its Implication for the New Evangelization [Czy wielu będzie zaoszczędzonych? To, co rzeczywiście uczy Sobór Watykański II i jego implikacja dla nowej ewangelizacji], William B. Eerdmans Publishing Company, Grand Rapids, Michigan 2012, s. 135.

8 G. Amirault, M. Amirault, dz. cyt.

9 Tamże.

10 Tamże.

11 Tamże.

12 Tamże. 
Nasuwa się sugestia dotycząca tego pierwszego podejścia, które pokazuje stan umysłu, w którym Ireneusz doszedł do tego wniosku. Po pierwsze, jeśli jest to cel do osiągnięcia, uzasadnione jest wnioskowanie, że ten drugi jest obrazą zdrowego rozsądku. Tą alternatywą jest wieczne cierpienie. Warto rozważyć, dlaczego nie miałoby to sensu oraz dlaczego nie jest to coś, co Bóg chciałby wziąć pod uwagę, ale najważniejsze jest, aby zauważyć, że to drugie podejście, które może zostać obrane, dotyczy wiecznej obecności zła, która sama w sobie nie jest pożądana. Innymi słowy, podczas gdy ludzie mogą dokonywać różnych wyborów, które przynoszą zło na świat, Bóg nie jest zainteresowany pozwalaniem złu dalej istnieć, zamiast tego wprowadzając proces oczyszczający. Może to również mieć wpływ na postrzeganie cierpienia, którego nie chcemy. Jeśli przyczyną cierpienia jest zło samo w sobie, to nie powinno mieć ono prawa dalej trwać, ponieważ zło nie powinno móc istnieć. Można by zapytać, czy jeśli jednak jest to jedyny argument Ireneusza, biorąc pod uwagę, że nie twierdził on, że cierpienie nie jest pożądane ze względu na zło. Te dwie tezy zostały postawione osobno ${ }^{13}$.

Można spekulować na temat przyczyn, dlaczego nie powinno istnieć wieczne cierpienie, lecz jego źródło i przedmiot są dwiema oczywistymi jego cechami. Omawiając zło, które jest przyczyną cierpienia, wyłania się istotny element jego natury. Innym zaś jest wybór osoby, która cierpi. Te dwa elementy są ze sobą ściśle powiązane. Można nawet twierdzić, że akt odrzucenia Boga, który przecież stworzył zło, jest dla Niego jeszcze bardziej obraźliwy. W związku z tym można zidentyfikować dwie główne zniewagi Boga, będąc w cierpieniu. Przedmiot cierpienia - człowiek, jest ukochany przez Boga. Wiemy o tym dzięki kilku deklaracjom miłości w Biblii. Kiedy człowiek odwraca się od Boga i sprowadza na świat zło, może zostać przez Niego odrzucony. Można wyobrazić sobie okoliczności, w których ma miejsce pojednanie, lecz wpierw istnieje stan rozłamu, spowodowany przewinieniem tej osoby. Gdy to przewinienie w jakiś sposób zostanie usunięte, możliwe staje się zjednoczenie. Ireneusz zdaje się wierzyć, że ten okres, znany jako piekło, mógłby zapewnić warunki dla zaistnienia tej przekształconej relacji między Stwórcą a stworzeniem ${ }^{14}$.

Teofil w pewien sposób wyjaśnia, jak mogło do tego dojść, opisując grzech piekielny jako wadę człowieka i piekło jako sposób usunięcia tych wad. Jego analogia stawia Boga na stanowisku rzemieślnika, wprowadzającego drobne zmiany w swoim stworzeniu. Zamiast postrzegania czasu spędzonego „tu i teraz”, jako czasu ostatecznego w życiu człowieka, wyobraża sobie długą wieczność

13 Por. J. Dupuis, Toward a Christian Theology of Religious Pluralism [W kierunku chrześcijańskiej teologii religijnego pluralizmu], Orbis, New York 1997, s. 60-66, 70-77.

14 Por. J. W. Hanson, Universalism: The Prevailing Doctrine of The Christian Church Druring Its First Five Hundred Years [Uniwersalizm, doktryna dominująca w Kościele chrześcijańskim w ciagu pierwszych pięciuset lat], Beloved Publishing, Middletown 2015, s. 58-60. 
rozciągającą się po śmierci i oczekuje, że Bóg wykorzysta ten czas, niemający końca, na udoskonalenie istoty stworzonej przez siebie ${ }^{15}$.

Diodor z Tarsu zakłada, że po śmierci kara za grzech nie będzie wieczna „W razie gdyby nieśmiertelność im przygotowana miałaby być ich wadą (...)"16. Zamiast tego domyśla się on, że „będą oni oczyszczani przez krótki czas, w zależności od ilości złych zamiarów w swoich czynach" ${ }^{17}$, zapominając na chwilę, że on także umrze i będzie sądzony. Rozumowanie to trudno uznać za logiczne. Dla Diodora z Tarsu jest oczywiste, że ta idea nieśmiertelności powinna służyć z korzyścią dla wszystkich istot ludzkich. Choć można krytykować go za niedoskonałą logikę. Wydaje się bowiem, że jest bardzo na miejscu zauważyć hojność ducha. Trudno rozpatrywać, aby w ogromnym darze, który został nam stworzony ze względu na nasze okoliczności, znajdowałby się tak straszny koszmar. Innymi słowy, Bóg stworzył wszystko tak, jak chciał. Sytuacja, w której wszyscy trwaliby na wieki, a wieczność ta byłaby nieprzyjemnym doświadczeniem dla grzeszników, nie została wzięta pod uwagę przez Diodora z Tarsu. Można podjąć dalej myśli zawarte w tym spostrzeżeniu i stwierdzić, że nie ma sensu posiadać rozumu dającego wnioskować, że dla niektórych z nas wieczność - powtarzając niedomówienie Diodora - byłaby „wadą”. Nasze rozumowanie powinno dostarczyć nam okno na świat, sposób rozumienia siebie, naszego Boga oraz tego, jak wszystko do siebie pasuje. Jeśli nie ma sensu sytuacja, w której niektórzy z nas cierpieliby wiecznie, może to być wskazówką, że taka sytuacja nie będzie miała miejsca.

Przy takiej różnorodności argumentów istnieje jednak szereg ważnych wątków. Jednym z nich jest ten, że życie po śmierci zostało zaprojektowane w taki sposób, aby nie przekraczało naszych możliwości moralnych do wyobrażenia go. Utwierdza nas to $\mathrm{w}$ przypuszczeniu wprowadzającym nas w bardzo zażyłe relacje z Bogiem, ponieważ zakłada, że wieczność jest wzorowana tak, aby miała sens dla nas ${ }^{18}$. Inny popularny wątek, podobny do poprzedniego, jest taki, że nasza sytuacja pozostanie ważna dla Boga, nawet jeśli popełnimy najbardziej haniebny czyn i pozostaniemy aż do śmierci nieskruszeni. Dla niektórych teologów i wielu innych katolików byłoby to trudne do zaakceptowania. Poza tym, powinna być jakaś konsekwencja czynów człowieka na ziemi. Dla kogoś, kto żyje zgodnie $\mathrm{z}$ wolą Bożą, w dużej mierze motywowany strachem przed karą, może być trudne do zaakceptowania odkrycie, że bez względu na to, co zrobi, wciąż po śmierci będzie istnieć pewien ratunek ${ }^{19}$. Należy jednak zapytać, czy odpowiednim jest przypuszczenie, że jest to coś, czego Bóg od nas oczekuje. Czy zasady, które zostały określone przez Boga są po prostu testem, który musimy zdać, aby być

15 G. Amirault, M. Amirault, dz. cyt.

16 Tamże.

17 Tamże.

18 Por. M. Kowalczyk, Teologia śmierci, „Communio” 32(2012), nr 3, s. 5-22

19 Por. J. Kijas, Tajemnica nieba, czyśćca i piekta, Święty Paweł, Częstochowa 2016, s. 213-217. 
z Nim? Albo może są to zasady dotyczące dobrego życia na ziemi? Dlaczego również mielibyśmy pragnąć wieczności dla każdego Bożego stworzenia, jako nieskończonego okresu cierpienia i męki? Czy byłoby to na podobieństwo Chrystusa? Można by się sprzeciwiać, że miłość Boga jest powodem tych wymagań, że nie może być nic gorszego niż grzech nieposłuszeństwa, i dlatego wierny wyznawca nie musi współczuć grzesznikom. Poza tym, wszyscy mamy wybór. Wraz z każdym wyborem przychodzą konsekwencje. To właśnie oznacza bycie dorosłym w świecie ${ }^{20}$.

Wcześni ojcowie Kościoła nie zgadzali się z takim poglądem. Oczywiście zostało to podkreślone w wielu miejscach, że poglądy wczesnych ojców Kościoła niekoniecznie są najlepsze. $Z$ biegiem czasu i dzięki pomocy społeczności teologów pracujących przez wieki, opracowano bardziej doskonałą doktrynę Kościoła, a zatem zrozumienie woli Bożej. Jak wiemy, apokatastaza została odrzucona przez Kościół katolicki, jednakże dialog o powszechnym zbawieniu jest ciągle możliwy, bez jednoczesnego odrzucenia realności istnienia piekła ${ }^{21}$. Mimo to, warto zacząć od początku chociażby po to, aby mieć pewność, że idea powszechnego zbawienia nie istnieje od niedawna, nie jest konsekwencją domagania się przez dekadenckich katolików wprowadzenia łatwiejszego zbioru zasad, ani też oddaleniem od pierwotnego ducha orędzia Chrystusa.

\section{3. ŚWIĘCI I ICH DOŚWIADCZENIE PIEKŁA}

Ponieważ powyższe historie są niepotwierdzone, nie można uznać ich za silny argument, ani za ani przeciw doktrynie. Służą one jednak ukazaniu, że najbardziej ukochani wśród wiernych Kościoła doświadczyli kontaktów z piekłem. Ci, którzy chcieliby zapoznać się z ideą powszechnego zbawienia w jej najszerszej i wolnej od osądu formie, w której nie ma miejsca na potępienie, muszą stawić czoło pobożnym, którzy napotkali go twarzą w twarz w tym życiu. Franciszkański ksiądz, bł. Ryszard od św. Anny, wstąpił do zakonu tuż po śmierci swojego przyjaciela, który tak przerażająco doświadczył piekła na ziemi, że jego życie zmieniło się całkowicie. Przed przemianą swojego serca ten młody człowiek był rozrzutnikiem i w noc swojego nawrócenia pił i zadawał się z nierządnicami, tak jak i jego przyjaciel, którego pozostawił po pijanemu, po czym wrócił do domu i padł na łóżko. Później, w nocy, wyrwał go ze snu jego pijany młody przyjaciel, który był tak zniekształcony, że wyglądał jak sam diabeł. Kiedy Ryszard zapytał, co się stało, zjawa wyjaśniła, że została zamordowana właśnie tej nocy i znajdowała się w bra-

20 Por. tamże, s. 256-259.

21 Por. D. Jaros, Szkic rozwiazywania problemu istnienia nieustającego piekła $i$ wiecznej miłości Boga, „Teologia w Polsce” (2008) 2,1, s. 126. 
mach piekła. Ukazała mu, że pod szatami demony i płomienie torturują ją, a potem zniknęła. Ryszardowi został oszczędzony ten los, gdyż zmówił wcześniej kilka „Zdrowaś Maryjo”, co było jego nawykiem z dzieciństwa, dzięki temu pozostał przy życiu. Udał się do pobliskiego klasztoru, opowiedział swoją historię i błagał o przyjęcie. Wstąpił więc do klasztoru pod wpływem świadectwa swojego przyjaciela $^{22}$.

Pewien kapłan zaś za życia opowiadał historię, utrzymując, że jest prawdziwa. Była to historia o kobiecie bogatej i o wysokim statusie społecznym. Przyszedł do niej w nocy jej partner i oświadczył, że przekonał się o istnieniu piekła. Powiedział stanowczo: „Piekło istnieje!” i chwycił ją za rękę. To doświadczenie było dla kobiety tak przykre, że zemdlała. Gdy się obudziła, zobaczyła, że miejsce na jej ramieniu, które dotknął partner, pokrywały oparzenia tak poważne, że uszkodziło jej skórę i ciało aż do kości. Okazało się również, że ślady jego stóp w komnacie zostały wypalone na dywanie. W końcu kobieta dowiedziała się, że poprzedniej nocy człowiek ten zatruł się alkoholem i umarł, zanim wszedł do jej sypialni ${ }^{23}$.

Inni także przysięgali, że doświadczyli piekła. Uznaje się za fakt, iż św. Teresa została zabrana do piekła ${ }^{24}$, tak jak s. Józefa Menéndez. Św. Gemma Galgani przeżyła bohaterskie zmagania z demonami, które dręczyły ją przez dłuższy czas i przybierały różne formy ${ }^{25}$. Dzieci, które widziały Matkę Boską w Fatimie, miały wizję piekła, co miało być przyczyną głębokiej zmiany ich życia i zwrócenia się $\mathrm{z}$ wielką pobożnością do Boga ${ }^{26}$. Ten ostatni szczegół, przemiana życia dzieci z Fatimy, może stanowić wskazówkę, dlaczego piekło i diabeł są nie tylko tolerowane, ale uznane za konieczne przez Boga. W przypadku św. Gemmy przypuszcza się także, że jej walka z demonami przyczyniła się do udoskonalenia jej duszy, pokazując, że rzecz nieprzyjemna może okazać się konieczną, w celu osiągnięcia ostatecznego dobra. Jeśli jest to intencją Boga i jeśli mamy przejść przez piekło i szatana, jako środek do oczyszczenia i większego związania z Bogiem, to może całe pojęcie piekła i szatana jest, jeśli nie błędne, to co najmniej nieprecyzyjne. W naszych ograniczonych umysłach często widzimy piekło jako karę ${ }^{27}$. Sami pragniemy zemsty, kiedy doznamy krzywdy, i postrzegamy świat przez pryzmat własnego doświadczenia. W rezultacie sądzimy, że gdy ktoś cierpi nie bezcelowo,

${ }^{22}$ G. Dallaire, Stories of Hell in the Lives of the Saints [Opowieści o piekle w życiu świętych] [online] http://www.mysticsofthechurch.com/2013/03/stories-of-hell-in-lives -of-saints.html (4.6.2016).

23 Tamże.

24 Teresa z Avilli, Życie św. Teresy, Wydawnictwo Głosu Karmelu, Kraków 1939, s. 451.

25 G. Galgani, Attacks by the Devil [Ataki diabła] [online] http://www.stgemmagalgani.com/2008/09/ saint-gemma-versus-devil.html (4.6.2016).

26 Por. Z. J. Kijas, Piekło wiecznym oddzieleniem od Boga, Edycja Świętego Pawła, Częstochowa 2004, s. 227-228.

27 Por. J. Zieliński. W kręgu Bożych tajemnic. Śmierć, czyściec, niebo, piekło, Wydawnictwo Karmelitów Bosych, Kraków 2005, s. 81. 
to musi to być jakiś rodzaj kary za wcześniejsze występki. Boża sprawiedliwość może równie dobrze działać w ten sposób i kto ma ją kwestionować? Ale może również mieć działanie podobne do tego, w jaki sposób Jezus usprawiedliwił cały świat. Jeśli diabeł i piekło są przeznaczone na narzędzia przemiany, to nadaje to większy sens istnieniu piekła, które nie będzie miejscem, gdzie ludzie zostaną pozostawieni i zapomniani na wieczność. Oczywiście, to również powoduje reakcję wewnątrz nas, w zależności od tego, czy uważamy, że ta kara powinna istnieć, czy nie, ale ważnym argumentem w tym miejscu nie jest pytanie, czy stosujemy się do naszego zmysłu dobra i zła, lecz pytanie: jaki rodzaj sprawiedliwości wybrał Bóg? Ostatecznie pozostaje to poza zasięgiem naszych możliwości, ale warto rozważyć nieskończone miłosierdzie Chrystusa i Jego nawoływania do postępowania w ten sposób, jaki On nam wskazuje. Czy dzięki temu Chrystus przybliża nas do bycia ludźmi takimi, jak Bóg chce, byśmy byli? Prawdopodobnie. Skoro więc tak jest, to ma sens, żeby miejsce cierpienia nie było miejscem cierpienia wiecznego, lecz zamiast tego służyło jako miejsce tymczasowego, oczyszczającego cierpienia.

Historie powyższych świętych i innych, którzy doświadczyli piekła na ziemi, zdają się potwierdzać tę hipotezę. Piekło jest przedstawiane jako zjawisko sprawiające pozytywną zmianę. Diabeł zostaje użyty w sposób, który najbardziej odpowiada Temu, który go stworzył. Mimo tego, że nigdy nie będziemy wiedzieć na pewno, to pogląd ten wydaje się sugerować pewną świętą proporcję i symetrię ${ }^{28}$. Św. Teresa od Dzieciątka Jezus została uznana za tak mądrą w rozumieniu Kościoła i jego nauki, że papież Jan Paweł II uczynił ją doktorem i specjalnym nauczycielem Kościoła ${ }^{29}$. Przedstawiła innym siostrom modlitwę, która wskazywała m.in., że każdy znajdzie przebaczenie. Argumentem przemawiającym za tym twierdzeniem jest to, że samym celem wcielenia Jezusa Chrystusa było właśnie to, aby uratować cały świat ${ }^{30}$. Jeśli powszechne zbawienie wydaje się komuś heretyckie, ważne jest, aby zauważyć, że argument św. Teresy jest tutaj dość silny. Przecież nie może istnieć inne rozumienie celów wizyty Chrystusa na ziemi, ani samego Kościoła, jak tylko dotarcie do wszystkich ludzi z dobrą nowiną o zbawieniu. Bóg bez wątpienia chce, aby całe jego stworzenie zostało zbawione. Uzasadnione jest zatem badanie możliwości, że Bóg dostaje to, czego chce. $Z$ drugiej jednak strony, nie można też całkowicie wykluczyć, że wolna wola człowieka sprawia, że niektórzy ludzie nie wybierają drogi Bożej. Nawet upadli aniołowie odważyli się zbuntować przeciwko Bogu, niektórzy ludzie robią to samo. Jeśli ostatecznie zostaną oni przywróceni do owczarni, czy naprawdę dokonają dobrego wyboru?

28 Por. tamże, s. 81-88.

29 Por. J. Huscenot, Doktorzy Kościoła, Edycja Świętego Pawła, Częstochowa 2002, s. 5-11.

30 Por. Benedict XVI, St. Theresa of Lisieux (General Audience St. Peter's Square, Wednesday, 6 April 2011), w: http://w2.vatican.va/content/benedict-xvi/en/audiences/2011/documents/hf_benxvi_aud_20110406.html (4.6.2016). 
Lub też, jak krnąbrne dzieci, które dopuściły się pomyłki, powinny ponieść konsekwencje, aby mogły zobaczyć swój błąd? ${ }^{31}$

Cel misji Chrystusa na ziemi jest właśnie tym źródłem, które zainspirowało św. Pawła do oświadczenia, że byłby skłonny iść do piekła dla zbawienia swych braci $^{32}$. To jest echem działania Chrystusa - wzięcie na siebie cierpienia i grzechów innych, aby uwolnić ich od skutków swojego postępowania. Taka głęboko empatyczna perspektywa nie może być tak od razu odrzucona, zwłaszcza że żyjemy w świecie, w którym jesteśmy tak bardzo zagrożeni obojętnością i wyborami, które czynią nas nieczułymi na cierpienie innych. Któż z nas nie może powiedzieć z całą pewnością, że nie stał się częściowo głuchy na wołanie ludzkości? Co więcej, kto może zaprzeczyć, że taka głuchota jest nawet mile widziana, że szaleństwem byłoby zająć miejsce cierpiących, gdybyśmy mieli zmierzyć się z okrucieństwem, cierpieniem i nieludzkością wokół nas? W związku z tym, możemy być niezdolni do osądzania tego, chyba najbardziej wrażliwego tematu - kto dostanie się do piekła, a kto nie (nikt w Kościele oficjalnie nie orzekł, że ktokolwiek tam trafił33). Tak wielu ludzi chce karać tych, którzy nie przestrzegają zasad. Jest to często bardziej podobne do wyżywania się na słabszych, niż do postawy bycia fair w stosunku do innych.

Sobór Watykański II zbliżył się znacznie bardziej do akceptacji powszechnego zbawienia niż być może wiele osób przypuszcza, gdyż zmienił stosunek Kościoła do tych, którzy nie zetknęli się z chrześcijaństwem. Kościół nie uważa tych ludzi za przeklętych, jak myśli wiele osób i robi wiele innych religii. Zamiast tego, Sobór Watykański II stwierdził, że: „Ci bowiem, którzy bez własnej winy nie znają Ewangelii Chrystusa i Jego Kościoła, szczerze sercem szukają Boga a Jego wolę poznania przez nakaz sumienia starają się pod wpływem łaski wypełniać w swoim postępowaniu, mogą osiągnąć wieczne zbawienie KK 16"34. Papież Jan Paweł II wychwycił to, co jest chyba najbardziej oczekiwaną konsekwencją tego poglądu wśród zwolenników powszechnego zbawienia, kiedy wyraził stanowisko, że „wieczne potępienie pozostaje możliwością, ale bez specjalnego objawienia Bożego nie jest nam dana wiedza, kto będzie potępiony i czy w ogóle ktokolwiek będzie" 35 . Podsumowując, należy stwierdzić że istnieje wiele tradycji w Kościele katolickim, które opowiadają się za pewnego rodzaju możliwością tzw. powszechnego zbawienia. Oczywiście, kilku wczesnych ojców Kościoła wydawało się popierać tę ideę, opartą w dużej mierze na poglądzie, że Bóg tak całkowicie kontroluje, że nawet nasze bunty są po prostu etapem w procesie powrotu na łono

31 Por. Z. J. Kijas, Piekło wiecznym oddzieleniem od Boga, dz. cyt., s. 352-361.

32 Por. Rz 9,3.

33 Por. J. Finkenzeller, dz. cyt., s. 215.

34 J. V. Schall, Universal Salvation: The Logic [Powszechne zbawienie: Logika] [online] http:// www.catholicworldreport.com/Item/2733/on_universal_salvation_the_logic.aspx (4.6.2016).

35 Tamże. 
Pana. Dla niektórych może to wydawać się odrzuceniem wolnej woli i bardzo obraźliwe w stosunku do tego, co wielu ludzi rozumie, jako Boży plan stworzenia. Być może większym zarzutem jest to, że sprawia to, iż konsekwencje nieposłuszeństwa są znacznie mniejsze niż obecnie jest to pojmowane. Niektórych może to przybliżyć do zrozumienia Bożego miłosierdzia, ale inni oczywiście będą urażeni tym, co wydaje im się być obrazą Boskiej sprawiedliwości. Jak to często bywa, polegając tylko na własnym zrozumieniu, trudno jest znaleźć w Biblii ostateczne stanowisko dotyczące powszechnego zbawienia. Aby mieć pewność, trzeba przypomnieć, że Chrystus przyszedł na ten świat, aby zbawić wszystkich ludzi ${ }^{36}$. Jednocześnie ostrzegł, że droga do zbawienia jest wąska ${ }^{37}$. Istnieją fragmenty, gdzie wydaje się, że Bóg na końcu czasów zamierza zbawić wszystkie swoje dzieci, inne zaś wykazują bardzo pewną rzeczywistość piekła i potępienia dla tych, którzy nie wypełniają Jego przykazań. Kwestia ta z pewnością wymaga boskiego oświecenia w zrozumieniu tekstu Pisma Świętego, ponieważ sądzi się, że można by wtedy udowodnić jedną z dwóch powyższych tez.

Wydaje się, że tak właśnie jest, gdyż prawdziwa odpowiedź musi być wyważona, nie będąc interpretacją dobra ani zła, lecz zrozumieniem, do jakiego stopnia Bóg chce, aby ludzkość miała wolną wolę, a także jak bardzo Bóg chce, aby wszyscy ludzie byli zebrani wokół Niego. Wymaga to wizji umysłu Boga i tylko Bóg ma o tym pojęcie. Święci bez wątpienia opisują piekło, jako miejsce prawdziwe. Wielu innych ludzi miało doświadczenia, które sugerują, że piekło musi istnieć nie tylko w celu przestraszenia ludzi i skłonienia do odpowiedniego zachowania, lecz ukarania ich za swoje postępowanie na tej ziemi. Te relacje świadków można odrzucić jako wymysły, ale aby to zrobić, trzeba zignorować rolę wiary w zrozumieniu świata duchowego tylko po to, żeby starać się uzyskać zrozumienie jednego jej aspektu. Zamiast tego, należy uznać, że miliony relacji dotyczących wizyt w piekle i demonów sugerują, że istnieje pewne źdźbło prawdy w zapewnieniach istnienia piekła, które jest wypełnione przynajmniej częściowo tymi, którzy odmawiają Bogu posłuszeństwa w ziemskim życiu ${ }^{38}$. Nie neguje to możliwości, czy raczej nadziei powszechnego zbawienia. Powoduje to poszerzenie spektrum możliwości. Ta interpretacja zakłada istnienie pewnego rodzaju piekła, które nie jest puste. Tak twierdzą święci i nie ma powodu, aby im nie wierzyć. Ostatecznie też nasza podróż do powszechnego zbawienia postawi nas twarzą w twarz z najbardziej grzesznymi i zatwardziałymi, którzy z różnych powodów nie chcą kochać Boga. Niektórzy zapytają, dlaczego w ogóle interesujemy się takimi osobami? Czy nie dokonali przecież umyślnego wyboru? Piekło jest właśnie jego konsekwencją. Musimy zadać sobie pytanie, jak blisko nasz własny osąd jest

\footnotetext{
36 Por. J 3,17; J 12,44-50.

37 Por. Mt 7,13.

38 Por. M. von Cochem, Cztery sprawy ostateczne, Exter Sp., Gdańsk 1995, s. 111-145.
} 
od Chrystusowego. Wybaczyć tym ludziom, oznaczałoby znaleźć miejsce w niebie dla wszystkich, nawet tych, którzy podczas życia na ziemi złamali wszystkie możliwe reguły bez wyrzutów sumienia. Otworzenie tym ludziom drogi do nieba oznacza również, że nikt nigdy nie skorzystałby ze swojej wolnej woli odrzucenia nieba. Dla niektórych będzie to w pewien sposób odrzucenie wolnej woli i trzeba zastanowić się czy naprawdę jest to konsekwencja wprowadzenia całej ludzkości do nieba. Czy Kościół pozwoli na taką interpretację, wydaje się wątpliwe, ale także nie do końca pewne. Św. Jan Paweł II stwierdza jasno, że jest to nie do pojęcia. Pozostaje nam zatem spekulować, chociaż mówi nam to tyle samo o samych sobie, co i o przeznaczeniu nieba i piekła ${ }^{39}$

Wspólnota katolicka przyjęła do wiadomości fakt istnienia piekła. Dzięki analizie Pisma Świętego i badaniom hierarchów Kościoła stało się jasne, że piekło jest bardzo realną częścią procesu udoskonalania istoty ludzkiej. Doktryny Kościoła były przez wieki modernizowane, lecz przesłanie to pozostaje obecnie jasne. Doktryna katolicka zmieniła swoje przesłanie z mówiącego o lęku na głoszące przebaczenie. Groźba potępienia wciąż jednak pozostaje. Rzeczywistość ta nie podlega już dyskusji. Wraz z możliwością potępienia istnieje możliwość odpłacenia za grzechy za pomocą uczciwej i odpowiedniej kary ${ }^{40}$. Za grzechy odpłacić można na niezliczoną ilość sposobów, w piekle, lub dzięki procesowi oczyszczania w czyśćcu. W Piśmie Świętym znajdują się nawiązania do opisów tych kar. Zostały one zinterpretowane z zachowaniem najlepszych starań. Bóg nasz jest Bogiem miłości i przebaczenia. Wraz z istnieniem piekła katolicy uznają istnienie wielu typów grzechów, stopni ich ciężkości, a także istnienie drogi, wiodącej do odkupienia za grzechy. Pismo Święte odpowiada na pytania dotyczące odkupienia i sposobu jego osiągnięcia. Obecne zrozumienie odkupienia zostało osiągnięte dzięki przeprowadzonym licznym dogłębnym badaniom Pisma Świętego. W oczywisty sposób miłość stanowi antytezę piekła. Człowiek posiada wolną wolę, a tych, którzy wybierają odrzucenie miłości, czeka proces oczyszczania. Droga do odkupienia jest mierzona stopniem grzechów popełnionych za życia. Pojęcie to jest dla nas, zwykłych śmiertelników, trudne do zrozumienia, kiedy rozmyślamy nad stopniem wszechobecnej grzeszności i oczywistego braku skruchy. Hierarchowie i uczeni Kościoła, jak np. Jan Paweł II, pocieszają, że prawdziwe zrozumienie zbawienia rodzaju ludzkiego pozostaje poza naszą możliwością obecnego zrozumienia.

Pojęcie piekła jest wszechobecne w niemal każdej kulturze na całym świecie. Chrześcijańskie przykłady definiują je, jako stan kary i męki w życiu pozagrobo-

39 Por. W. Hryniewicz, Mąrość serca. 18 rozmów o nadziei i miłosierdziu, Wydawnictwo WAM, Kraków 2016, s. 159-215.

40 Por. J.C. Sasia, The Future Life [Przyszłe życie], Aeterna Press, Londyn 2015, s. 1-8; B.J. Groeschel, After this life. What Catholic believe about what happens next [Po tym życiu. W co katolicy wierza co się stanie po śmierci], Our Sunday Visitor, Indiana 2009, s. 11-16. 
wym, a jeszcze inne kultury religijne uważają to za miejsce zamieszkania zmarłego. Artykuł ten jest próbą studium powszechnego zbawienia i wyborów dokonywanych przez ludzi za życia, a także powodów ostatecznie doprowadzających ich do takich wyborów. Tematyka rozważania obejmie kontemplację osobistego losu, losów bliskich oraz losów wszystkich ludzi. Artykuł ten przedstawia krótką historię tego tematu, począwszy od koncepcji wczesnych ojców Kościoła, dotyczących zbawienia. Historia ta rozwija się wraz z badaniem Pisma Świętego, żywotów świętych (bezpośrednio odnoszących się do zbawienia) oraz czyśćca. W konsekwencji treść artykułu koncentruje się na koncepcji wolnego wyboru i wiary oraz zajmuje się pojęciami nieba i piekła, czyśćca i życia na ziemi, pozostającymi poza zasięgiem naszego ludzkiego rozumienia.

\section{Bibliografia}

Amirault G., Amirault M., The Church Fathers on Universalism [Ojcowie Kościoła o uniwersalizmie], http://www.tentmaker.org/Quotes/churchfathersquotes.htm (3.6.2016).

Balthasar von H.U., Dare We Hope "That All men Be Saved"? [Możemy mieć nadzieje że wszyscy będa zbawieni], Ignatius Press San Francisco 2014.

Benedict XVI, St. Theresa of Lisieux (General Audience St. Peter's Square, Wednesday, 6 April 2011), w: http://w2.vatican.va/content/benedict-xvi/en/audiences/2011/documents/hf_ben-xvi_aud_20110406.html (4.6.2016).

Cochem M. Von., Cztery sprawy ostateczne, Exter Sp., Gdańsk 1995.

Dallaire G., Stories of Hell in the Lives of the Saints [Opowieści o piekle w życiu świętych] (online) http://www.mysticsofthechurch.com/2013/03/stories-of-hell-in-lives -of-saints.html (4.6.2016).

Dupuis J., Toward a Christian Theology of Religious Pluralism [W kierunku chrześcijańskiej teologii religijnego pluralizmu], Orbis, New York 1997.

Finkenzeller J., Eschatologia. Podręcznik teologii dogmatycznej, Wydawnictwo M, Kraków 1995.

Gemma Galgani św., Attacks by the Devil [Ataki diabła] [online] http://www. stgemmagalgani.com/2008/09/saint-gemma-versus-devil.html (4.6.2016).

Huscenot J., Doktorzy Kościoła, Edycja Świętego Pawła, Częstochowa 2002.

Hryniewicz H., Mądrość serca. 18 rozmów o nadziei i miłosierdziu, Wydawnictwo WAM, Kraków 2016.

Jaros D., Szkic rozwiąywania problemu istnienia nieustajacego piekła i wiecznej mitości Boga, „Teologia w Polsce” (2008), nr 1, s. 121-161.

Kijas, Z.J., Tajemnica nieba, czyśćca i piekta, Święty Paweł, Częstochowa 2016.

Kijas Z.J., Piekło wiecznym oddzieleniem od Boga, Święty Paweł, Częstochowa 2004. 
Kowalczyk M., Zbawczy wymiar nadziei w encyklice Benedykta XVI Spe salvi, „Ateneum Kapłańskie” 103(2012), t. 158, z. 3, s. 507-524.

Kowalczyk M., Teologia śmierci, „Communio” 32(2012), nr 3, s. 5-22.

Martin R., The Urgency of the New Evangelization: Answering the Call. [Pilność nowej ewangelizacji: odpowiadanie na wezwanie], Our Sunday Visitor, Indiana 2013.

Parzyszek C., Nowa Ewangelizacja - droga Kościoła do nadziei, Apostolicum, Ząbki 2010.

Parzyszek C., Znaczenie nowej ewangelizacji dla odnowy wspótczesnego świata, Apostolicum, Ząbki, 2012.

Sasia J.C., The Future Life. [Przyszłe życie] Our Sundau Visitor, Londyn 2015.

Schall J.V., Universal Salvation: The Logic [Powszechne zbawienie: Logika] [online] http://www.catholicworldreport.com/Item/2733/on_universal_salvation_the_logic.aspx (4.6.2016).

Zieliński J., W kręgu Bożych tajemnic. Śmierć, czyściec, niebo, piekło, Wydawnictwo Karmelitów Bosych, Kraków 2005.

Teresa z Avila, Życie św. Teresy, Wydawnictwo Głosu Karmelu, Kraków 1939.

\section{Streszczenie}

Pojęcie piekła jest wszechobecne w niemal każdej kulturze na całym świecie. Chrześcijańskie przykłady definiują je, jako stan kary i męki w życiu pozagrobowym, a jeszcze inne kultury religijne uważają to za miejsce zamieszkania zmarłego. Artykuł ten jest próbą studium powszechnego zbawienia i wyborów dokonywanych przez ludzi za życia, a także powodów ostatecznie doprowadzających ich do takich wyborów. Tematyka rozważania obejmuje kontemplację osobistego losu, losów bliskich oraz losów wszystkich ludzi. Artykuł ten przedstawia krótką historię tego tematu. Punkt pierwszy przedstawia oznaki nadziei powszechnego zbawienia w Biblii oraz odpowiedzialność za stan naszej duszy i troskę o zbawienie naszych najbliższych. Punkt drugi przywołuje nauczanie ojców Kościoła, których uważa się za aprobujących koncepcję powszechnego zbawienia oraz podkreślenie, że ich poglądy niekoniecznie są najlepsze. W trzecim punkcie przedstawione żywoty świętych (nie można uznać ich za silny argument ani „za”, ani „przeciw” doktrynie odnoszącej się do zbawienia oraz czyśćca) są jednak warte do przytoczenia. Artykuł ten koncentruje się na koncepcji wolnego wyboru oraz konsekwencji tego wyboru i wiary. Zajmuje się również pojęciami nieba i piekła, czyśćca i życia na ziemi, pozostającymi poza zasięgiem naszego ludzkiego rozumienia. Schemat tego artykuły z całą pewnością nie wyczerpuje całego zagadnienia nowych sugestii o piekle po drugim Soborze Watykańskim, ale daje nam pewien szkic odnowionego rozumienia rzeczywistości piekła. Wskazuje także na powagę ludzkich wyborów, które zdecydują, jak będzie wyglądało życie wieczne człowieka. I choć 
rzeczywistość piekła dla współczesnego człowieka (który bardziej podkreśla i woli się skupiać na nieskończonym Bożym miłosierdziu) jest czymś trudnym do zaakceptowania i zrozumienia, to jest jednak prawdą naszej wiary.

Slowa kluczowe: cierpienie, śmierć, sąd Boży, nadzieja, miłosierdzie, zbawienie, wolny wybór, piekto, wizje świętych, apokatastaza

New Suggestions on the Knowledge of Hell

\section{Summary}

The concept of hell is ubiquitous in almost every culture around the world. The Christian sources define it as a state of punishment and torment in the afterlife while other religious cultures consider it a place of residence of the deceased. This article is an attempt to study the subject of the universal salvation. The historical part of the paper deals with the issue of the hope of the universal salvation in the Bible as well as the responsibility for of one's soul and the care for the salvation of ourselves and our loved ones.

The second chapter of the article invokes some of the Church fathers who shared and promoted the idea of the universal salvation. Now we know that their views were not necessarily in accordance with the teaching of the Church. The final chapter focuses on the lives of saints and their personal visions of hell (even though they cannot be considered as strong arguments for or against the doctrine of the universal salvation). In addition to this, the article contains an analysis of the concept of the free choice, its consequences and faith. It also deals with the ideas of heaven and hell, purgatory and this world which are all beyond the reach of our human understanding.

The paper certainly does not exhaust the entirety of the new input to the understanding of hell after the Second Vatican Council but it outlines the renewed theological reflexion this reality. It also points to the problem of the seriousness of the human choices that determine what our life will be like through the eternity. The reality of hell for the contemporary man (who emphasises the infinite Divine Mercy) is nevertheless something difficult to accept and understand, yet it is a truth of our faith.

Key words: Suffering, death, last judgment, hope, mercy, salvation, free will, hell, revelations of saints, apocatastasis 